\title{
Infant Feeding, Vitamin D and IgE Sensitization to Food Allergens at 6 Years in a Longitudinal Icelandic Cohort
}

\author{
Birna Thorisdottir ${ }^{1,2, *(0)}$, Ingibjorg Gunnarsdottir ${ }^{1}$, Anna Gudrun Vidarsdottir ${ }^{3}$, \\ Sigurveig Sigurdardottir ${ }^{3,4,5}$, Bryndis Eva Birgisdottir ${ }^{1}$ and Inga Thorsdottir ${ }^{6}$ \\ 1 Unit for Nutrition Research, Faculty of Food Science and Nutrition, School of Health Sciences, University of \\ Iceland and Landspitali University Hospital, 101 Reykjavik, Iceland \\ 2 Faculty of Sociology, Anthropology and Folkloristics, School of Social Sciences, University of Iceland, \\ 101 Reykjavik, Iceland \\ 3 Department of Immunology, Landspitali University Hospital, 101 Reykjavik, Iceland \\ 4 Faculty of Medicine, University of Iceland, 101 Reykjavik, Iceland \\ 5 The Allergy Outpatient Department, Landspitali University Hospital, 108 Reykjavik, Iceland \\ 6 School of Health Sciences, University of Iceland, 101 Reykjavik, Iceland \\ * Correspondence: bth50@hi.is
}

Received: 14 June 2019; Accepted: 19 July 2019; Published: 23 July 2019

\begin{abstract}
Nordic Nutrition Recommendations (NNR) recommend exclusive breastfeeding until 6 months, partial breastfeeding until 1 year or longer and irrespective of breastfeeding, avoiding solid foods before 4 months. Strong evidence was found for benefits of breastfeeding regarding growth and infections but limited/inconclusive evidence regarding atopic disease and asthma. Vitamin D is of special interest in the Nordic diet. The aim of this prospective study was to compare infant feeding and vitamin D between immunoglobulin E ( $\operatorname{IgE})$ sensitized $(n=14)$ and non-sensitized $(n=130)$ children at 6 years. Information on diet and vitamin D supplement use were collected with dietary recall ( $<5$ months), 1 -d food records ( 5 and 6 months) and 3-d weighed food records (12 months and 6 years). Serum-specific IgE-antibodies against milk, egg, cod, wheat, soy and peanut (cut-off specific $\operatorname{IgE} \geq 0.35 \mathrm{kUA} / \mathrm{L}$ ) were measured at 6 years and serum 25 -hydroxyvitamin $\mathrm{D}$ at 12 months and 6 years. At 4 months, $57 \%$ of IgE sensitized vs. $23 \%$ of non-sensitized children $(p<0.01)$ had received solid food. At 12 months, IgE sensitized children had a lower intake of vitamin D (median (25th, 75th percentiles): $3.9 \mu \mathrm{g} / \mathrm{d}(3.2,7.2)$ vs. $8.1 \mu \mathrm{g} / \mathrm{d}(4.4,12.3), p=0.03)$ and at 6 years, fewer used vitamin $\mathrm{D}$ supplements regularly ( $23 \%$ vs. $56 \%, p=0.03$ ). Introduction of solid foods prior to 4 months increased the odds of IgE-sensitization, $O R=4.9(95 \%, C I=1.4-16.6)$ and vitamin D supplement at 6 years decreased the odds of IgE-sensitization, $O R=0.2(95 \%, C I=0.1-0.98)$, adjusting for maternal smoking. These observations support the NNR in their recommendation against introducing complementary solid foods before the age of 4 months. Furthermore, they support encouraging vitamin D intake for young children at northern latitudes.
\end{abstract}

Keywords: Nordic diet; infants; children; recommendations; IgE sensitization; breastfeeding; complementary feeding; solid food; vitamin D

\section{Introduction}

Dietary approaches to preventing food allergies are currently the topic of much research and may have implications for infant nutrition recommendations [1,2]. The Nordic Nutrition Recommendations (NNR) recommend exclusive breastfeeding until the infant is about 6 months old [3]. The frequency of breastfeeding is high in the Nordic countries: Data from 2006-2012 show that about 95\% of newborns 
are breastfed and $68 \%-85 \%$ still receive any amount of breastmilk at the age of four months [4]. The most recent data from Denmark, Norway and Sweden, show similar values for breastfeeding [5-7]. Most Nordic infants, however, receive complementary foods before the age of 6 months in Denmark, Finland, Iceland, Norway and Sweden. At the age of 4 months, 23\%-63\% are exclusively breastfed, falling to $0 \%-12 \%$ at the age of 6 months [4]. The Nordic Nutrition Recommendations on breastfeeding state that some infants will need complementary feeding before 6 months of age, but they emphasize that solid food should not be introduced before the age of 4 months [3]. While most official bodies recommend exclusive breastfeeding for either the first 6 months or at least 4-6 months for health-related endpoints [3,8-10], there is a debate regarding the optimal age of introduction of solid food as primary prevention to reduce atopy and allergy [1]. The systematic literature review on breastfeeding prepared for the Nordic Nutrition Recommendations gave the lowest grade of evidence for any preventive effects of breastfeeding on the risk of atopic diseases in children, so no conclusions were drawn, while for most other undesirable outcomes there was convincing or probable evidence for the protective effects of breastfeeding [4]. Similarly, recent systematic literature reviews found the data inconclusive regarding the effect of breastfeeding on the risk of atopic diseases [11,12].

Due to the northern latitude, vitamin D is of special importance in the Nordic countries. In the NNR as well as national guidelines in all Nordic countries, parents are advised to give vitamin D supplements $(10 \mu \mathrm{g} / \mathrm{d})$ to their infants [3]. The importance of vitamin D supplement intake for vitamin D status at 12 months and 6 years of age in an Icelandic longitudinal cohort has been reported [13,14]. While vitamin D deficiency in infancy or childhood has been associated with higher immunoglobulin E (IgE) levels and sensitization to food allergens [15,16], other studies suggest that infant vitamin D supplementation increases the risk of later atopy and allergy [17-19].

The detection of serum-specific IgE to common food allergens indicates a state of sensitization, although in isolation it does not prove the existence of clinical allergy [20]. Studies have suggested that about half of sensitized children have a food allergy, clinically proven by food challenge [21]. However, according to a model by Grimshaw et al., primary prevention of allergies should focus on preventing immunological sensitization [2]. Therefore, we decided to test for serum-specific IgE to common food allergens at 6 years in the Icelandic longitudinal cohort with detailed information of the timing of solid food introduction and repeated information on the use of vitamin D supplements throughout the first year of life and in a follow-up at 6 years. Our aim was to compare feeding in infancy and vitamin D intake between sensitized and non-sensitized children.

\section{Materials and Methods}

\subsection{Participants and Design}

Previous publications have described in detail the study population (a random sample of 250 Icelandic infants born in 2005), recruitment and data collection throughout the first year of life and at follow-up at 6 years [22,23]. The inclusion criteria were Icelandic (Caucasian) parents, singleton birth, 37-41 weeks gestational length, birth weight within 10th-90th percentiles, absence of birth defects or congenital long-term diseases and regular antenatal care of the mother. The current study includes 144 children who participated in blood sampling in the follow-up at 6 years and had allergen-specific IgE levels analyzed ( $84 \%$ of the children in the follow-up). As previously described, children participating in the blood sampling did not differ from the original sample in birth size and breastfeeding [24] and the basic characteristics of subjects included in this study did not differ from other subjects in the follow-up. Informed written consent from the parents was obtained for the study and all participant information was processed with strict confidentiality. The study was conducted according to the Declaration of Helsinki, approved by the National Bioethics Committee (VSNb2005040019/037; VSNb2011010008/037) and registered at the Data Protection Authority (S2449/2005; S5099/2011) in Iceland. 


\subsection{Dietary Assessments}

Detailed information about infant feeding from birth until 4 months (17 weeks) including breastfeeding, the introduction of infant formula and solid food and use of vitamin D or other dietary supplements were gathered with one structured dietary recall facilitated by a trained interviewer (mean infant age at dietary recall 21 weeks). The exact age when the first infant formula and first solid food was introduced to the diet, along with the type of formula or solid was registered. At 5 and 6 months, non-weighed intake was registered for 1 day $(24 \mathrm{~h})$ and at 12 months and 6 years weighed food records were kept for 3 consecutive days $(72 \mathrm{~h}$ ), thereof two weekdays and one weekend day (either Sunday-Tuesday or Thursday-Saturday). All food and fluids were weighed on accurate scales (Philips type HR 2385, Hungary and Austria) with $1 \mathrm{~g}$ precision. Dietary supplements and medicines were also registered. An average daily consumption of food and nutrients was calculated using the Icelandic food composition database [25] which included infant products, such as porridges, purées and cereals. Total vitamin D intake included vitamin D from food and supplements. Vitamin D supplement doses were most often between 6 and $10 \mu \mathrm{g} / \mathrm{d}$. Since the doses did not differ greatly in amount, participants were classified as using vitamin D supplements if they received any amount of cod liver oil or another type of vitamin D containing supplement.

\subsection{Blood Sampling and Biochemical Analysis}

At 12 months and 6 years, venous blood samples were collected in the morning in a fasting state at Landspitali University Hospital by a certified pediatrician and centrifuged within $6 \mathrm{~h}$ of collection. Separated serum samples were stored at $-80{ }^{\circ} \mathrm{C}$ at the biobank at Landspitali until analyses were carried out by biomedical scientists at Landspitali for serum 25(OH)D at 12 months (April 2013), serum 25(OH)D at 6 years (December 2013) and serum-specific IgE to food allergens at 6 years (January 2014).

Serum 25(OH)D levels were analyzed using an electro-chemiluminescence immunoassay (Elecsys Vitamin D total assay, Modular Analytics E170, Roche Diagnostics, Mannheim, Germany) (measuring range $7.5-175.0 \mathrm{nmol} / \mathrm{L}$, precision $0.1 \mathrm{nmol} / \mathrm{L}$ ). Tests were performed according to the manufacturer's instructions [26].

Specific IgE levels were analyzed using ImmunoCAP fluoroenzyme immunoassay (Phadia 250, Thermo Scientific, Uppsala, Sweden) (precision $0.01 \mathrm{kUA} / \mathrm{L}$ ) for ImmunoCAP ${ }^{\circledR}$ allergen Fx5, a food mix test detecting specific IgE to six major food allergens in children (cow's milk, egg white, cod, wheat, soybean and peanut). Tests were performed according to the manufacturer's instructions and classified as a positive test, using the term 'IgE sensitized', when specific $\operatorname{IgE} \geq 0.35 \mathrm{kUA} / \mathrm{L}$. In the case of a positive test, specific IgE was further analyzed for each of the 6 major food allergens.

\subsection{Other Variables}

Background characteristics were chosen based on their availability in the original data and possible associations with sensitization according to literature, e.g., season of birth [27], urban living [28], firstborn child [29] and parental smoking during infancy [30,31]. Prior analyses of the data have shown maternal education and maternal BMI to be the variables most associated with breastfeeding duration and adherence to infant diet recommendations [32].

Information on parental variables including age, education, self-reported weight and height (from which BMI was calculated) and smoking after birth, as well as information on the infant's siblings, was gathered from structured questionnaires answered by parents (usually the mother) when the children were 12 months old. Parents' education was defined as the highest level of completed education categorized as basic education (finished elementary school) or longer based on earlier publications [32]. Birth months were categorized as 'winter/spring' (November-April) and 'summer/autumn' (May-October) based on the expected contribution of sunlight exposure to maternal vitamin D status around birth [13]. During follow-up at 6 years of age, parents answered another questionnaire including questions on children's regular use of antihistamines and asthma inhalers. 
The questionnaires were constructed for the primary outcomes of the study (dietary intake and growth) and did not include questions about family history of atopy or maternal vitamin D supplementation during pregnancy or lactation.

Information about weight, length and head circumference was gathered from maternity wards (birth measurements) and primary healthcare facilities (as close to ages 2,6 and 12 months as possible). Weight was registered with $5 \mathrm{~g}$ precision, length measured on length boards and registered with $0.1 \mathrm{~cm}$ precision and head circumference was registered with $0.1 \mathrm{~cm}$ precision. At follow-up, (mean age $73.4 \pm 3.2$ months) weight (Marel M series 110, Iceland) (precision $0.1 \mathrm{~kg}$ ) and height (Ulmer stadiometer, Professor Heinze, Busse design, Ulm, Germany) (precision $0.1 \mathrm{~cm}$ ) were measured at Landspitali University Hospital. Children were classified as being a normal weight or overweight/obese at 6 years according to the World Health Organization's (WHO) growth reference data for 5-19 years [33] and the age-specific International Obesity Task Force (IOTF) cut-off points used in previous publications from this cohort [34]. Gains in infant weight, length or head circumference were calculated for each participant as the difference in measurements between two time points.

\subsection{Statistical Analyses}

Statistical analyses were performed with SAS (Enterprise Guide 4.3; SAS Institute Inc, Cary, NC, USA). Variables were examined for normality using quantile-quantile plots. Categorical variables were presented as $n(\%)$ and a chi-square used for comparison between groups. Normally distributed continuous variables were presented as mean and standard deviations (SD) and compared using two-sided t-tests. Non-normally distributed continuous variables were presented as medians and 25th to 75th percentiles and compared using the non-parametric Mann-Whitney U-test. Logistic regression analyses were used to examine possible associations with sensitization at 6 years, adjusting for maternal smoking during infancy, and presented as the odds ratio (OR) with its $95 \%$ confidence intervals (CI). The level of significance was set at $\leq 0.05$.

\section{Results}

Fourteen 6-year-old children (10\%) were IgE sensitized, thereof eight to cow's milk only; two to cow's milk and eggs; two to peanuts only; one to peanuts and eggs; and one to peanuts, wheat and soy. Four IgE sensitized children and one non-sensitized child were reported as regular users of asthma inhalers or antihistamine at 6 years. Table 1 presents the characteristics of the participants included in this study. Two IgE sensitized children (15\%) vs. four non-sensitized children (3\%) had mothers who reported smoking in the first year of the child's life $(p \leq 0.05)$. Other background characteristics did not differ significantly between the groups. Looking at infant growth, IgE sensitized children gained significantly more weight and increased their head circumference significantly more in the first 2 months of life than non-sensitized children. At 2-6 months and 6-12 months (data not shown), no significant differences in weight gain or head circumference growth were observed. Depending on the applied method, $16 \%$ of non-sensitized vs. 36\% of IgE sensitized (WHO method, non-significant (NS), $p=0.07$ ) or $10 \%$ of non-sensitized vs. $29 \%$ of IgE sensitized (IOTF method, $p=0.04$ ) were classified as overweight/obese at 6 years.

Breastfeeding initiation rate was high (99\%) and $88 \%$ of infants were still breastfed when introduced to solid food. Neither exclusive breastfeeding, nor mixed breastmilk and infant formula or exclusively infant formula, in the first year differed according to sensitization status. The average duration of exclusive breastfeeding was $3.6 \pm 1.9$ months for non-sensitized children vs $2.9 \pm 2.1$ months for the IgE sensitized (NS). The average duration of any breastfeeding was similar for non-sensitized vs sensitized children. At 4 months 36\% of IgE sensitized vs. $60 \%$ of non-sensitized children were exclusively breastfed (NS, $p=0.08$ ). However, as shown in Figure 1, a greater proportion of IgE sensitized than non-sensitized children had been introduced to complementary solid food at or before 4 months of age (17 weeks) (57\% vs. $23 \%$, respectively, $p<0.01)$. Introduction of solid foods prior to 4 months increased the odds for sensitization, $O R=4.9(95 \% \mathrm{CI}=1.4-16.6)$ when adjusted for maternal smoking. 
Table 1. Characteristics of the participants included in the study $(n=144)$.

\begin{tabular}{|c|c|c|c|}
\hline & Non-Sensitized $n=130$ & IgE Sensitized $n=14$ & $p$ \\
\hline \multicolumn{4}{|l|}{ Infant information } \\
\hline Boys, $n(\%)$ & $65(50)$ & $9(64)$ & 0.31 \\
\hline Birth in winter/spring, $n(\%)$ & $70(54)$ & $8(57)$ & 0.81 \\
\hline Urban living, $n(\%)$ & $91(70)$ & $11(79)$ & 0.50 \\
\hline First born, $n(\%)$ & $42(36)$ & $2(17)$ & 0.18 \\
\hline Exclusive breastfeeding, months & $4(2,5)$ & $4(0,4)$ & 0.18 \\
\hline Any breastfeeding, months & $8(6,10)$ & $8(7,11)$ & 0.97 \\
\hline Weight gain $0-2$ months, $\mathrm{kg}$ & $1.8 \pm 0.5$ & $2.2 \pm 0.4$ & 0.04 \\
\hline Weight gain 2-6 months, $\mathrm{kg}$ & $2.4 \pm 0.7$ & $2.3 \pm 0.7$ & 0.59 \\
\hline Length gain $0-6$ months ${ }^{1}, \mathrm{~cm}$ & $16.8 \pm 2.0$ & $17.8 \pm 1.7$ & 0.09 \\
\hline $\begin{array}{l}\text { Head circumference gain } \\
0-2 \text { months, } \mathrm{cm}\end{array}$ & $4.2 \pm 1.0$ & $4.9 \pm 1.2$ & 0.02 \\
\hline $\begin{array}{l}\text { Head circumference gain } \\
2-6 \text { months, cm }\end{array}$ & $4.2 \pm 0.7$ & $3.9 \pm 0.8$ & 0.15 \\
\hline \multicolumn{4}{|l|}{ Parent information ${ }^{2}$} \\
\hline Maternal smoking, $n(\%)$ & $4(3)$ & $2(15)$ & 0.05 \\
\hline Paternal smoking, $n(\%)$ & $18(16)$ & $3(23)$ & 0.49 \\
\hline Maternal age, years & $31.3 \pm 4.8$ & $33.2 \pm 5.4$ & 0.18 \\
\hline Paternal age, years & $34.1 \pm 5.7$ & $36.5 \pm 6.6$ & 0.16 \\
\hline Maternal BMI, kg/m² & $23.5(21.4,26.5)$ & $26.6(21.8,33.2)$ & 0.21 \\
\hline Paternal BMI, kg/m² & $26.0(24.3,28.1)$ & $26.6(23.4,28.7)$ & 0.82 \\
\hline Basic education mother ${ }^{3}, n(\%)$ & $19(16)$ & $4(31)$ & 0.19 \\
\hline Basic education father ${ }^{3}, n(\%)$ & $26(23)$ & $4(31)$ & 0.52 \\
\hline
\end{tabular}

Data presented as $n(\%)$, mean \pm SD or median (25th, 75th percentiles). Chi-square, two-sided $t$-test or Mann-Whitney U-test used for comparison between groups. ${ }^{1}$ Length gain $0-2$ months and 2-6 months not reported due to a large number of missing values for length at 2 months (missing $n=56$ ). ${ }^{2}$ From questionnaire answered when the infant is 12 months old. ${ }^{3}$ Elementary school (10 years in school) is the highest level of completed education.
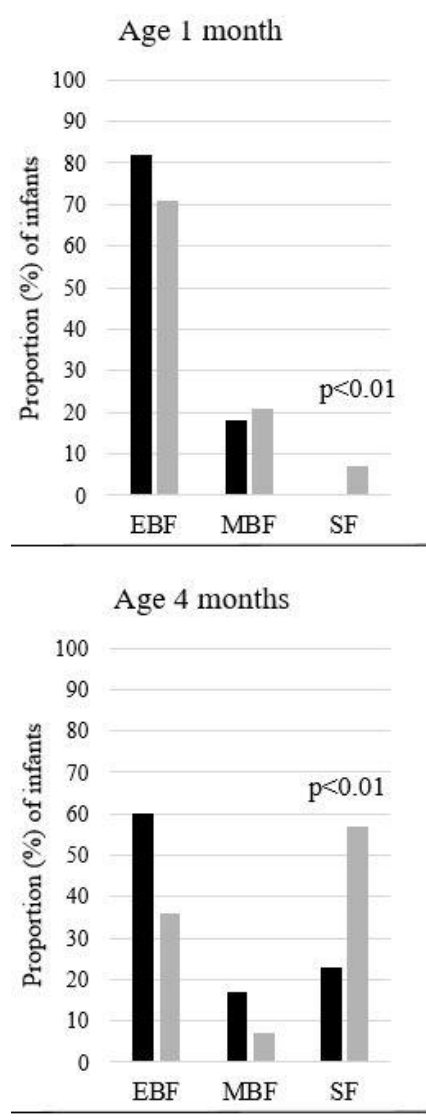

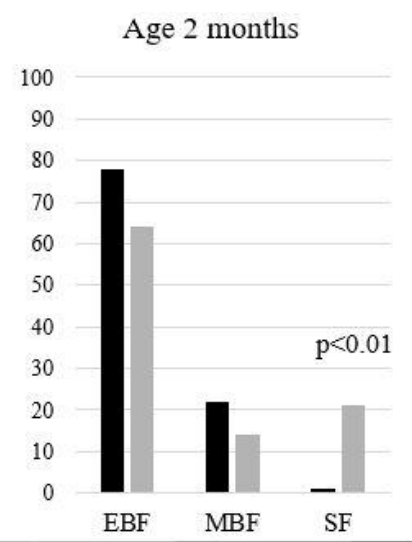

Age 5 months

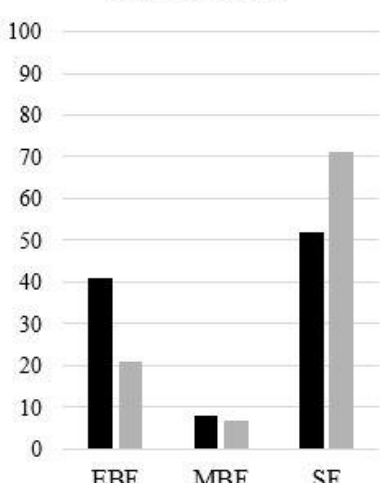

Age 3 months

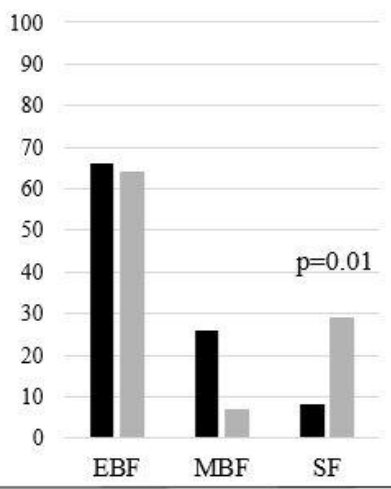

Age 6 months

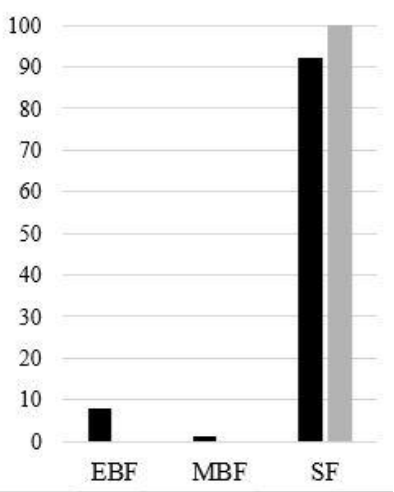

- Non-sensitized $\backsim \mathrm{IgE}$-sensitized

Figure 1. Proportion (\%) of infants aged 1-6 months receiving exclusively breastmilk (EBF); mixed breastmilk and infant formula or exclusively infant formula (MBF); or any solid food (SF), shown for non-sensitized $(n=130)$ and $\operatorname{IgE}$ sensitized children $(n=14)$. 
Total vitamin D intake at 12 months was lower among IgE sensitized than non-sensitized children, presented as median (25th, 75th percentiles): $3.9 \mu \mathrm{g} / \mathrm{d}(3.2,7.2) \mathrm{vs} .8 .1 \mu \mathrm{g} / \mathrm{d}(4.4,12.3)$, respectively, $p=0.03$. This could partly be explained by less but non-significant vitamin D supplement use among IgE sensitized children (see Figure 2) and partly by less consumption of vitamin D fortified formula (consumed by $30 \%$ of IgE sensitized vs. $68 \%$ of non-sensitized children at 12 months, $p=0.02$ ). Higher vitamin $D$ intake at 12 months was associated with a decreased odds for sensitization, $O R=0.8(95 \%$, $\mathrm{CI}=0.7-0.996)$ when adjusted for maternal smoking. As shown in Figure 2, IgE sensitized children were less likely than non-sensitized children to use vitamin D supplements at 6 years of age ( $23 \% \mathrm{vs.} 56 \%$, $p=0.03$ ). Vitamin D supplement use at 6 years was associated with a decreased odds for sensitization, $O R=0.2(95 \%, C I=0.1-0.98)$, when adjusted for maternal smoking. The median intake of vitamin $\mathrm{D}$ at 6 years was $3.1 \mu \mathrm{g} / \mathrm{d}(2.1,3.6)$ vs. $5.3 \mu \mathrm{g} / \mathrm{d}(2.3,12.4)$ among IgE sensitized vs. non-sensitized children, respectively (NS, $p=0.09$ ). Mean serum 25(OH)D did not differ between IgE sensitized and non-sensitized children, at either 12 months ( $96.8 \pm 33.6$ vs. $99.3 \pm 32.2 \mathrm{nmol} / \mathrm{L}$, respectively) or 6 years $(59.3 \pm 15.9$ vs. $56.0 \pm 16.7 \mathrm{nmol} / \mathrm{L}$, respectively). It should be noted that only half of participants had serum 25(OH)D measured at 12 months (69 non-sensitized and 7 IgE sensitized).

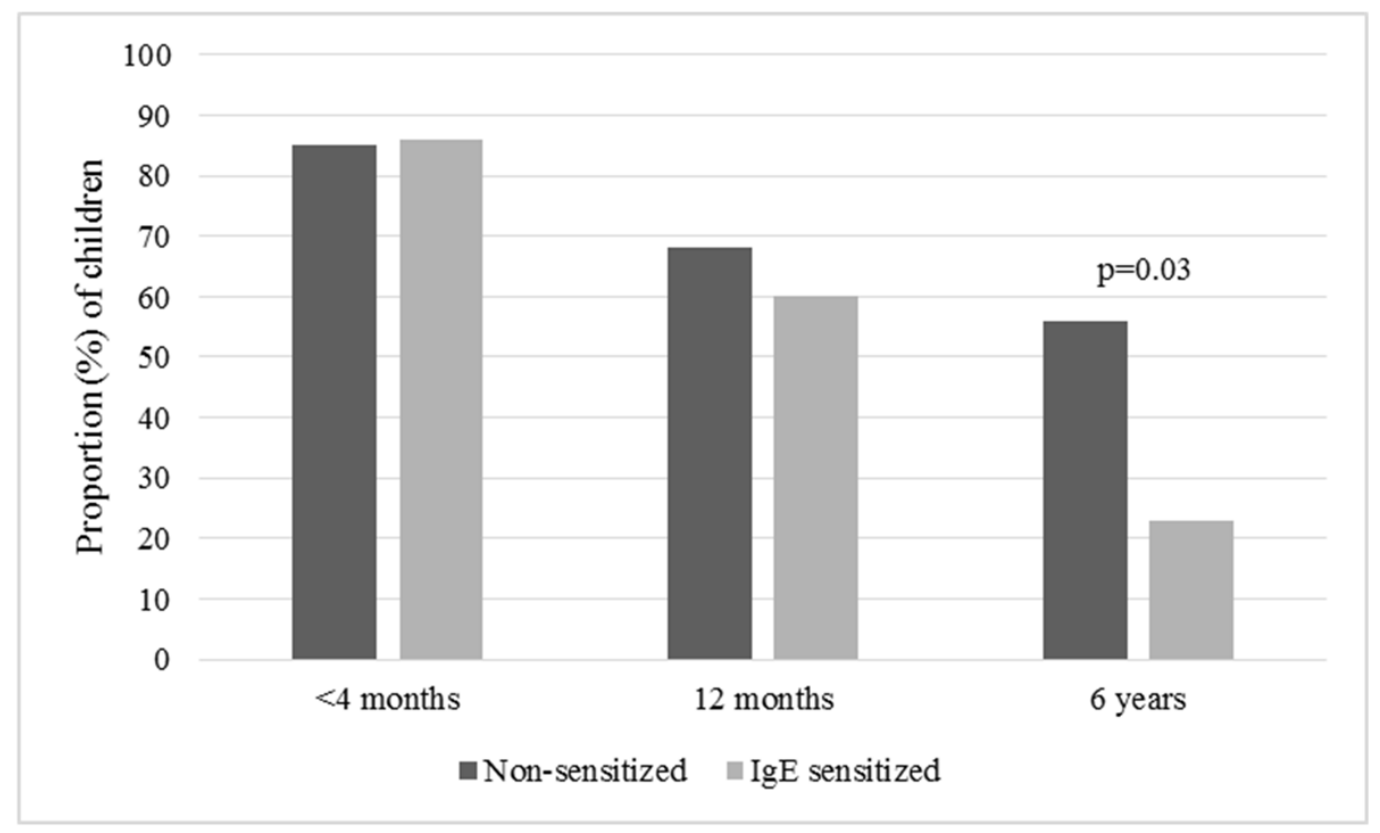

Figure 2. Proportion (\%) of children of selected ages using vitamin D supplements, shown for non-sensitized $(n=130)$ and $\operatorname{IgE}$ sensitized $(n=14)$ children.

\section{Discussion}

In this population-based study of Icelandic children, solid food introduction prior to 4 months was more common and total vitamin D intake at 12 months was lower among IgE sensitized vs. non-sensitized children. Furthermore, vitamin D supplement use at 6 years was less common among IgE sensitized children. Logistic models adjusted for maternal smoking (the only background variable that differed significantly according to sensitization), confirmed these results.

The results add to the present literature about early life exposures on IgE outcomes in childhood, although this study is small and cannot determine causality. Also, a 9.7\% IgE sensitization ratio at 6 years is higher than found in other studies of Icelandic children, measured at a younger age [35-37]. Although we did not have clinical information on food allergies, increased serum levels of specific IgE detected by immunoassay are commonly associated with a higher likelihood of clinical atopic disease or food allergy [38-40] and the prevention of sensitization is considered important for the prevention of food allergies [2]. Therefore, our results of $57 \%$ of $\operatorname{IgE}$ sensitized vs. $23 \%$ of non-sensitized children 
having been introduced to solid food at 4 months support the Nordic Nutrition Recommendations advice to delay complementary feeding until the infant is at least 4 months of age. They also seem to support the current vitamin D supplementation recommendations in Iceland and the Nordic countries. We did not observe significant differences in any or exclusive breastfeeding between IgE sensitized and non-sensitized children, although there was a trend $(p=0.08)$ suggesting that IgE sensitized children had lower rates of exclusive breastfeeding in infancy compared to non-sensitized children (36\% vs. $60 \%$ at 4 months, respectively).

Literature suggests that by 4 months, the infant's gut is sufficiently developed to receive and digest solid food or any food beyond breastmilk and infant formula [41,42]. Associations between the reduced relative abundance of potentially immunomodulatory gut bacteria and the development of IgE-associated eczema have also been suggested [43]. While some studies [44-47] but not all [48,49] propose that introduction of allergenic solid food from 3-4 months of age is safe and may lead to tolerance and protection against IgE-mediated food allergy, associations between solid food introduction prior to 4 months, faster infant growth and childhood obesity have been reported [50-54]. Our findings indicate interesting differences between the $\operatorname{IgE}$ sensitized and non-sensitized children in growth rate in infancy and perhaps also in the prevalence of body weight above the normal reference value at 6 years. Infant feeding (breastfeeding or early introduction of solid foods) may be a confounder in this, e.g., through higher infant energy and/or protein intake. Faster weight gain in infancy has been associated with an increased risk of allergic rhinitis [55], asthma [56-59], impaired lung function [60-62] and wheezing $[55,63]$. To the best of our knowledge, other studies have not observed the trend we see on less gain in postnatal head circumference among IgE sensitized children compared to their non-sensitized peers. It has been hypothesized that childhood obesity may promote immunological changes increasing the risk for allergy [64] but the evidence remains uncertain [65]. Previous papers from the currently studied population-based Icelandic cohort born in the year 2005, with extensive and detailed information on both dietary intake and growth throughout the first year of life and follow-up at 6 years of age, have shown associations between infant nutrition and growth up to 6 years. Solid food prior to 6 months of age and high protein intake and especially animal protein intake at 9-12 months has been associated with a body mass index above the normal range at the age of 6 years $[23,66,67]$.

A Cochrane review from 2016 found no evidence to disagree with recommendations for healthy infants of exclusive breastfeeding for the first 6 months [68]. A more recent systematic review found moderate evidence suggesting that a short breastfeeding duration, or no breastfeeding, was associated with a higher risk of childhood asthma [11]. The same review found limited evidence for the effect of either a short breastfeeding duration or no breastfeeding on food allergies, allergic rhinitis and atopic dermatitis [11]. Another systematic literature review found limited to strong evidence, depending on the food in question, to suggest that introducing allergenic foods after 4 months of age does not affect the risk of food allergy and atopic dermatitis/eczema but may decrease the risk of later peanut and egg allergies [12]. Findings summarized in these reviews, and other papers, have resulted in changes to the older dietary advice about avoiding allergenic foods during the first year of life. Further studies are needed with a focus on diet in infancy and atopic disease, but our results on solid food introduction harmonize with these recent systematic reviews.

Vitamin D intake is important for all infants as well as children and adults with little sun exposure in all Nordic countries. Official recommendations in Iceland put special emphasis on vitamin D intake from the diet and supplements due to the country's geographical location at $63-66^{\circ} \mathrm{N}$, resulting in limited endogenous vitamin D synthesis for many months of the year $[69,70]$. It has been hypothesized that the relationship between vitamin D status and allergy may not be linear and that both low and high vitamin D status may be associated with elevated IgE levels [71]. While childhood vitamin D deficiency has been associated with increased asthma risk [72] and higher levels of IgE sensitization [15,16], other studies, from Finland, Sweden and Australia suggest that infant vitamin D supplementation may increase the risk for atopy and allergy later in life [17-19]. In the Northern Finland Birth Cohort 1966, the majority of infants used vitamin D supplements in doses of $50 \mu \mathrm{g} / \mathrm{d}$ [17], which is considered 
the upper limit for children, and too high in the first year of life [3]. In our cohort, no 12-month-old infant was considered vitamin D deficient (25-hydroxyvitamin $\mathrm{D}<30 \mathrm{nmol} / \mathrm{L}$ ) and vitamin $\mathrm{D}$ intake from diet and supplements combined did not exceed $25 \mu \mathrm{g} / \mathrm{d}$ in infancy or at 6 years [13,14]. A recent Icelandic study reported associations between postnatal cod liver oil consumption and decreased food sensitization and clinical food allergy in infants [35]. The present study found lower total vitamin D intake at 12 months and lower vitamin D supplement use (mainly cod liver oil) at 6 years among IgE sensitized children compared to non-sensitized. Previous work on this data has shown correlations between vitamin D supplement use in late infancy and at 6 years [73]. It is possible that children using vitamin D supplements at 6 years have been more likely than others to use vitamin D supplements from 1-6 years of age and it may therefore be viewed as a proxy for vitamin D supplement use in early childhood. We did not see a difference in vitamin D status by sensitization, but the small sample size may have weighted very heavily there, especially if the relationship between vitamin $\mathrm{D}$ and sensitization may not be linear [71]. We did not have information about maternal vitamin D intake during pregnancy or lactation.

Cod liver oil is a good source of both vitamin D and n-3 PUFA. Vitamin D modulates the action of immune cells, such as T and B cells, monocytes and dendritic cells, in an interplay between the innate and adaptive immune systems [74]. We cannot exclude an effect from the intake of n-3 PUFA on IgE sensitization in the current study [75].

The strength of our study lies in the detailed longitudinal data on infant feeding, vitamin D supplement use and growth from birth to 6 years in a population-based sample, which makes it an important contribution to the literature. The thorough and direct methods of data collection decrease unexplained variabilities and increase the validity of the data. For the investigated population at northern latitudes the results on vitamin D intake are important.

We acknowledge that our study is limited by the number of participants, resulting, for example, in wide confidence intervals, and results should therefore be cautiously interpreted, but the cohort's size was sufficiently large for the findings we observe. There is no reason to think the sample selection process influenced the results or affected feeding practices or vitamin D supplementation. Also, the representativeness of the sample is good. Therefore the significant effects or associations observed do firmly exist, although other associations cannot be excluded. The inclusion criteria; born at term, Icelandic (Caucasian) parents and absence of disease, must however be kept in mind when interpreting the results and may limit the generalizability of the findings.

\section{Conclusions}

The results support the NNR on not introducing complementary solid food before the age of 4 months and encouraging vitamin D intake from diet and supplements for Nordic infants and children. The results also indicated interesting differences between the IgE sensitized and non-sensitized children in growth rate in infancy and perhaps also in prevalence of body weight above the normal reference value at 6 years, which warrant further studies. Although not significant, we observed lower rates of exclusive breastfeeding in infancy for IgE sensitized children compared with non-sensitized children, which could be investigated in a larger sample.

Author Contributions: I.T. is the principal investigator for the longitudinal infant study. B.T. wrote the original draft. I.T., B.T. and I.G. were responsible for the data collection and the data analysis. A.G.V. and S.S. contributed to the blood analysis and interpretation. B.T. and B.E.B. were responsible for the statistical analysis and interpretation. All authors (B.T., I.G., A.G.V., S.S., B.E.B. and I.T.) contributed to the project conception, study plan, critical review and approved the final version of the manuscript.

Funding: This study was supported by the University of Iceland with a doctoral grant [HI15120056] and a grant from the University of Iceland Research Fund [2014-2016], Landspitali University Hospital [A-2016-034] and the Icelandic Centre for Research [050424031].

Acknowledgments: The authors express their appreciation to the staff at the Children's Hospital and laboratories at Landspitali University Hospital for their cooperation, students and other staff for their contribution to data 
collection and Thorhallur Ingi Halldorsson for verifying the statistical analysis. Last but not least the authors would like to thank the participating children and their families.

Conflicts of Interest: The authors declare no conflict of interest.

\section{References}

1. Ierodiakonou, D.; Garcia-Larsen, V.; Logan, A.; Groome, A.; Cunha, S.; Chivinge, J.; Robinson, Z.; Geoghegan, N.; Jarrold, K.; Reeves, T.; et al. Timing of allergenic food introduction to the infant diet and risk of allergic or autoimmune disease: A systematic review and meta-analysis. JAMA 2016, 316, 1181-1192. [CrossRef] [PubMed]

2. Grimshaw, K.; Logan, K.; O’Donovan, S.; Kiely, M.; Patient, K.; van Bilsen, J.; Beyer, K.; Campbell, D.E.; Garcia-Larsen, V.; Grabenhenrich, L.; et al. Modifying the infant's diet to prevent food allergy. Arch. Dis. Child. 2017, 102, 179-186. [CrossRef] [PubMed]

3. Nordic Council of Ministers. Nordic Nutrition Recommendations 2012: Integrating Nutrition and Physical Activity; Nordic Council of Ministers: Copenhagen, Denmark, 2014.

4. Hornell, A.; Lagstrom, H.; Lande, B.; Thorsdottir, I. Breastfeeding, introduction of other foods and effects on health: A systematic literature review for the 5th Nordic nutrition recommendations. Food Nutr. Res. 2013, 57, 20823. [CrossRef] [PubMed]

5. Sundhedsdatastyrelsen. Den Nationale Børnedatabase (BDB). Available online: https: //sundhedsdatastyrelsen.dk/da/registre-og-services/om-de-nationale-sundhedsregistre/graviditetfoedsler-og-boern/boernedatabasen (accessed on 6 June 2019).

6. Lande, B.; Helleve, A. Amming og Spedbarns Kosthold. Landsomfattende Undersøkelse; Rapport 2013; Helsedirektoratet: Oslo, Norway, 2014.

7. Socialstyrelsen-The National Board of Health and Welfare. Statistics on breastfeeding 2016. In Official Statistics of Sweden. Health and Medical Care; Art. no. 2018-2019-2013; The National Board of Health and Welfare: Stockholm, Sweden, 2018; ISSN 1400-3511.

8. Greer, F.R.; Sicherer, S.H.; Burks, A.W. Effects of early nutritional interventions on the development of atopic disease in infants and children: The role of maternal dietary restriction, breastfeeding, timing of introduction of complementary foods, and hydrolyzed formulas. Pediatrics 2008, 121, 183-191. [CrossRef] [PubMed]

9. Chan, E.S.; Cummings, C. Dietary exposures and allergy prevention in high-risk infants: A joint statement with the Canadian society of allergy and clinical immunology. Pediatr. Child Health 2013, 18, 545-554. [CrossRef] [PubMed]

10. Muraro, A.; Halken, S.; Arshad, S.H.; Beyer, K.; Dubois, A.E.; Du Toit, G.; Eigenmann, P.A.; Grimshaw, K.E.; Hoest, A.; Lack, G.; et al. EAACI food allergy and anaphylaxis guidelines. Primary prevention of food allergy. Allergy 2014, 69, 590-601. [CrossRef] [PubMed]

11. Gungor, D.; Nadaud, P.; LaPergola, C.C.; Dreibelbis, C.; Wong, Y.P.; Terry, N.; Abrams, S.A.; Beker, L.; Jacobovits, T.; Jarvinen, K.M.; et al. Infant milk-feeding practices and food allergies, allergic rhinitis, atopic dermatitis, and asthma throughout the life span: A systematic review. Am. J. Clin. Nutr. 2019, 109, 772s-799s. [CrossRef] [PubMed]

12. Obbagy, J.E.; English, L.K.; Wong, Y.P.; Butte, N.F.; Dewey, K.G.; Fleischer, D.M.; Fox, M.K.; Greer, F.R.; Krebs, N.F.; Scanlon, K.S.; et al. Complementary feeding and food allergy, atopic dermatitis/eczema, asthma, and allergic rhinitis: A systematic review. Am. J. Clin. Nutr. 2019, 109, 890s-934s. [CrossRef] [PubMed]

13. Thorisdottir, B.; Gunnarsdottir, I.; Steingrimsdottir, L.; Palsson, G.I.; Birgisdottir, B.E.; Thorsdottir, I. Vitamin D intake and status in 6-year-old Icelandic children followed up from infancy. Nutrients 2016, 8, 75. [CrossRef] [PubMed]

14. Thorisdottir, B.; Gunnarsdottir, I.; Steingrimsdottir, L.; Palsson, G.I.; Thorsdottir, I. Vitamin D intake and status in 12-month-old infants at 63-66 $\mathrm{N}$. Nutrients 2014, 6, 1182-1193. [CrossRef] [PubMed]

15. Sharief, S.; Jariwala, S.; Kumar, J.; Muntner, P.; Melamed, M.L. Vitamin D levels and food and environmental allergies in the United States: Results from the National health and nutrition examination survey 2005-2006. J. Allergy Clin. Immunol. 2011, 127, 1195-1202. [CrossRef] [PubMed]

16. Baek, J.H.; Shin, Y.H.; Chung, I.H.; Kim, H.J.; Yoo, E.G.; Yoon, J.W.; Jee, H.M.; Chang, Y.E.; Han, M.Y. The link between serum vitamin $\mathrm{D}$ level, sensitization to food allergens, and the severity of atopic dermatitis in infancy. J. Pediatr. 2014, 165, 849-854. [CrossRef] [PubMed] 
17. Hypponen, E.; Sovio, U.; Wjst, M.; Patel, S.; Pekkanen, J.; Hartikainen, A.L.; Jarvelinb, M.R. Infant vitamin D supplementation and allergic conditions in adulthood: Northern Finland birth cohort 1966. Ann. N. Y. Acad. Sci. 2004, 1037, 84-95. [CrossRef] [PubMed]

18. Kull, I.; Bergstrom, A.; Melen, E.; Lilja, G.; van Hage, M.; Pershagen, G.; Wickman, M. Early-life supplementation of vitamins $\mathrm{A}$ and $\mathrm{D}$, in water-soluble form or in peanut oil, and allergic diseases during childhood. J. Allergy Clin. Immunol. 2006, 118, 1299-1304. [CrossRef] [PubMed]

19. Hughes, A.M.; Lucas, R.M.; Ponsonby, A.L.; Chapman, C.; Coulthard, A.; Dear, K.; Dwyer, T.; Kilpatrick, T.J.; McMichael, A.J.; Pender, M.P.; et al. The role of latitude, ultraviolet radiation exposure and vitamin D in childhood asthma and hayfever: An Australian multicenter study. Pediatr. Allergy Immunol. Off. Publ. Eur. Soc. Pediatr. Allergy Immunol. 2011, 22, 327-333. [CrossRef]

20. Hamilton, R.G.; Oppenheimer, J. Serological IgE analyses in the diagnostic algorithm for allergic disease. J. Allergy Clin. Immunol Pract. 2015, 3, 833-840. [CrossRef] [PubMed]

21. Eigenmann, P.A. Do we still need oral food challenges for the diagnosis of food allergy? Pediatr. Allergy Immunol. Off. Publ. Eur. Soc. Pediatr. Allergy Immunol. 2018, 29, 239-242. [CrossRef]

22. Thorisdottir, A.V.; Thorsdottir, I.; Palsson, G.I. Nutrition and iron status of 1-year olds following a revision in infant dietary recommendations. Anemia 2011, 2011, 986303. [CrossRef]

23. Thorisdottir, B.; Gunnarsdottir, I.; Palsson, G.I.; Halldorsson, T.I.; Thorsdottir, I. Animal protein intake at 12 months is associated with growth factors at the age of six. Acta Paediatr. 2014, 103, 512-517. [CrossRef]

24. Thorisdottir, A.V.; Gunnarsdottir, I.; Palsson, G.I.; Gretarsson, S.J.; Thorsdottir, I. Iron status and developmental scores in 6-year-olds highlights ongoing need to tackle iron deficiency in infants. Acta Paediatr. 2013, 102, 914-919. [CrossRef]

25. Matis. The Icelandic Food Composition Database ISGEM. Available online: http://www.matis.is/neytendur/ naeringargildi-matvaela/um-gagnagrunninn/ (accessed on 6 July 2018).

26. Roche Diagnostics. Vitamin D Total. 25-Hydroxyvitamin D Manual; Roche Diagnostics: Mannheim, Germany, 2013.

27. Matsui, T.; Tanaka, K.; Yamashita, H.; Saneyasu, K.I.; Tanaka, H.; Takasato, Y.; Sugiura, S.; Inagaki, N.; Ito, K. Food allergy is linked to season of birth, sun exposure, and vitamin D deficiency. Allergol. Int. Off. J. Jpn. Soc. Allergol. 2019, 68, 172-177. [CrossRef] [PubMed]

28. Elholm, G.; Linneberg, A.; Husemoen, L.L.; Omland, O.; Gronager, P.M.; Sigsgaard, T.; Schlunssen, V. The Danish urban-rural gradient of allergic sensitization and disease in adults. Clin. Exp. Allergy J. Br. Soc. Allergy Clin. Immunol. 2016, 46, 103-111. [CrossRef] [PubMed]

29. Strachan, D.P.; Ait-Khaled, N.; Foliaki, S.; Mallol, J.; Odhiambo, J.; Pearce, N.; Williams, H.C. Siblings, asthma, rhinoconjunctivitis and eczema: A worldwide perspective from the International study of asthma and allergies in childhood. Clin. Exp. Allergy J. Br. Soc. Allergy Clin. Immunol. 2015, 45, 126-136. [CrossRef] [PubMed]

30. Ciaccio, C.E.; Gentile, D. Effects of tobacco smoke exposure in childhood on atopic diseases. Curr. Allergy Asthma Rep. 2013, 13, 687-692. [CrossRef] [PubMed]

31. Thacher, J.D.; Gruzieva, O.; Pershagen, G.; Neuman, A.; van Hage, M.; Wickman, M.; Kull, I.; Melen, E.; Bergstrom, A. Parental smoking and development of allergic sensitization from birth to adolescence. Allergy 2016, 71, 239-248. [CrossRef] [PubMed]

32. Thorisdottir, A.V.; Gunnarsdottir, I.; Thorsdottir, I. Revised infant dietary recommendations: The impact of maternal education and other parental factors on adherence rates in Iceland. Acta Paediatr. 2013, 102, 143-148. [CrossRef]

33. World Health Organization. Growth Reference Data for 5-19 Years; WHO Reference: Geneva, Switzerland, 2007; Available online: www.who.int/growthref/en (accessed on 4 July 2019).

34. Cole, T.J.; Bellizzi, M.C.; Flegal, K.M.; Dietz, W.H. Establishing a standard definition for child overweight and obesity worldwide: International survey. BMJ Clin. Res. 2000, 320, 1240-1243. [CrossRef]

35. Clausen, M.; Jonasson, K.; Keil, T.; Beyer, K.; Sigurdardottir, S.T. Fish oil in infancy protects against food allergy in Iceland-Results from a birth cohort study. Allergy 2018, 73, 1305-1312. [CrossRef]

36. Clausen, M.; Kristjansson, S.; Haraldsson, A.; Bjorksten, B. High prevalence of allergic diseases and sensitization in a low allergen country. Acta Paediatr. 2008, 97, 1216-1220. [CrossRef] 
37. Kristinsdottir, H.; Clausen, M.; Ragnarsdottir, H.S.; Halldorsdottir, I.H.; McBride, D.; Beyer, K.; Sigurdardottir, S.T. Prevalence of food allergy in Icelandic infants during first year of life. Laeknabladid 2011, 97, 11-18.

38. Longo, G.; Berti, I.; Burks, A.W.; Krauss, B.; Barbi, E. IgE-mediated food allergy in children. Lancet 2013, 382, 1656-1664. [CrossRef]

39. Laan, M.P.; Baert, M.R.; Bijl, A.M.; Vredendaal, A.E.; De Waard-van der Spek, F.B.; Oranje, A.P.; Savelkoul, H.F.; Neijens, H.J. Markers for early sensitization and inflammation in relation to clinical manifestations of atopic disease up to 2 years of age in 133 high-risk children. Clin. Exp. Allergy J. Br. Soc. Allergy Clin. Immunol. 2000, 30, 944-953. [CrossRef]

40. Kulig, M.; Bergmann, R.; Klettke, U.; Wahn, V.; Tacke, U.; Wahn, U. Natural course of sensitization to food and inhalant allergens during the first 6 years of life. J. Allergy Clin. Immunol. 1999, 103, 1173-1179. [CrossRef]

41. Fewtrell, M.; Bronsky, J.; Campoy, C.; Domellof, M.; Embleton, N.; Fidler Mis, N.; Hojsak, I.; Hulst, J.M.; Indrio, F.; Lapillonne, A.; et al. Complementary feeding: A position paper by the European society for paediatric gastroenterology, hepatology, and nutrition (ESPGHAN) committee on nutrition. J. Pediatr. Gastroenterol. Nutr. 2017, 64, 119-132. [CrossRef] [PubMed]

42. Naylor, A.J.; Morrow, A. (Eds.) Developmental Readiness of Normal Full Term Infants to Progress from Exclusive Breastfeeding to the Introduction of Complementary Foods: Reviews of the Relevant Literature Concerning Infant Immunologic, Gastrointestinal, Oral Motor and Maternal Reproductive and Lactational Development; Academy for Educational Development, The LINKAGES Project, Wellstart International: Washington, DC, USA, 2001.

43. West, C.E.; Ryden, P.; Lundin, D.; Engstrand, L.; Tulic, M.K.; Prescott, S.L. Gut microbiome and innate immune response patterns in IgE-associated eczema. Clin. Exp. Allergy J. Br. Soc. Allergy Clin. Immunol. 2015, 45, 1419-1429. [CrossRef] [PubMed]

44. Perkin, M.R.; Logan, K.; Tseng, A.; Raji, B.; Ayis, S.; Peacock, J.; Brough, H.; Marrs, T.; Radulovic, S.; Craven, J.; et al. Randomized trial of introduction of allergenic foods in breast-fed infants. N. Engl. J. Med. 2016, 374, 1733-1743. [CrossRef] [PubMed]

45. Du Toit, G.; Roberts, G.; Sayre, P.H.; Bahnson, H.T.; Radulovic, S.; Santos, A.F.; Brough, H.A.; Phippard, D.; Basting, M.; Feeney, M.; et al. Randomized trial of peanut consumption in infants at risk for peanut allergy. N. Engl. J. Med. 2015, 372, 803-813. [CrossRef]

46. Wei-Liang Tan, J.; Valerio, C.; Barnes, E.H.; Turner, P.J.; Van Asperen, P.A.; Kakakios, A.M.; Campbell, D.E. A randomized trial of egg introduction from 4 months of age in infants at risk for egg allergy. J. Allergy Clin. Immunol. 2017, 139, 1621-1628. [CrossRef]

47. Nwaru, B.I.; Takkinen, H.M.; Niemela, O.; Kaila, M.; Erkkola, M.; Ahonen, S.; Tuomi, H.; Haapala, A.M.; Kenward, M.G.; Pekkanen, J.; et al. Introduction of complementary foods in infancy and atopic sensitization at the age of 5 years: Timing and food diversity in a Finnish birth cohort. Allergy 2013, 68, 507-516. [CrossRef]

48. Grimshaw, K.E.; Maskell, J.; Oliver, E.M.; Morris, R.C.; Foote, K.D.; Mills, E.N.; Roberts, G.; Margetts, B.M. Introduction of complementary foods and the relationship to food allergy. Pediatrics 2013, 132, e1529-e1538. [CrossRef]

49. Bellach, J.; Schwarz, V.; Ahrens, B.; Trendelenburg, V.; Aksunger, O.; Kalb, B.; Niggemann, B.; Keil, T.; Beyer, K. Randomized placebo-controlled trial of hen's egg consumption for primary prevention in infants. J. Allergy Clin. Immunol. 2017, 139, 1591-1599. [CrossRef] [PubMed]

50. Daniels, L.; Mallan, K.M.; Fildes, A.; Wilson, J. The timing of solid introduction in an 'obesogenic' environment: A narrative review of the evidence and methodological issues. Austr. N. Z. J. Public Health 2015, 39, 366-373. [CrossRef] [PubMed]

51. Durmus, B.; Heppe, D.H.; Gishti, O.; Manniesing, R.; Abrahamse-Berkeveld, M.; van der Beek, E.M.; Hofman, A.; Duijts, L.; Gaillard, R.; Jaddoe, V.W. General and abdominal fat outcomes in school-age children associated with infant breastfeeding patterns. Am. J. Clin. Nutr. 2014, 99, 1351-1358. [CrossRef] [PubMed]

52. Grote, V.; Schiess, S.A.; Closa-Monasterolo, R.; Escribano, J.; Giovannini, M.; Scaglioni, S.; Stolarczyk, A.; Gruszfeld, D.; Hoyos, J.; Poncelet, P.; et al. The introduction of solid food and growth in the first $2 \mathrm{y}$ of life in formula-fed children: Analysis of data from a European cohort study. Am. J. Clin. Nutr. 2011, 94, 1785s-1793s. [PubMed] 
53. Huh, S.Y.; Rifas-Shiman, S.L.; Taveras, E.M.; Oken, E.; Gillman, M.W. Timing of solid food introduction and risk of obesity in preschool-aged children. Pediatrics 2011, 127, e544-e551. [CrossRef] [PubMed]

54. Weng, S.F.; Redsell, S.A.; Swift, J.A.; Yang, M.; Glazebrook, C.P. Systematic review and meta-analyses of risk factors for childhood overweight identifiable during infancy. Arch. Dis. Child. 2012, 97, 1019-1026. [CrossRef] [PubMed]

55. Anderson, E.L.; Fraser, A.; Martin, R.M.; Kramer, M.S.; Oken, E.; Patel, R.; Tilling, K. Associations of postnatal growth with asthma and atopy: The PROBIT Study. Pediatr. Allergy Immunol. Off. Publ. Eur. Soc. Pediatr. Allergy Immunol. 2013, 24, 122-130. [CrossRef] [PubMed]

56. Matos, S.M.; Jesus, S.R.; Saldiva, S.R.; Prado, M.S.; D'Innocenzo, S.; Assis, A.M.; Rodrigues, L.C.; Alcantara-Neves, N.M.; Cruz, A.A.; Simoes, S.D.M.; et al. Weight gain in the first two years of life, asthma and atopy: The SCAALA cohort study. Public Health Nutr. 2014, 17, 2537-2545. [CrossRef] [PubMed]

57. Sonnenschein-van der Voort, A.M.; Jaddoe, V.W.; Raat, H.; Moll, H.A.; Hofman, A.; de Jongste, J.C.; Duijts, L. Fetal and infant growth and asthma symptoms in preschool children: The generation R study. Am. J. Respir. Critic. Care Med. 2012, 185, 731-737. [CrossRef]

58. Tedner, S.G.; Ortqvist, A.K.; Almqvist, C. Fetal growth and risk of childhood asthma and allergic disease. Clin. Exp. Allergy J. Br. Soc. Allergy Clin. Immunol. 2012, 42, 1430-1447. [CrossRef]

59. Ortqvist, A.K.; Lundholm, C.; Carlstrom, E.; Lichtenstein, P.; Cnattingius, S.; Almqvist, C. Familial factors do not confound the association between birth weight and childhood asthma. Pediatrics 2009, 124, e737-e743. [CrossRef] [PubMed]

60. Lucas, J.S.; Inskip, H.M.; Godfrey, K.M.; Foreman, C.T.; Warner, J.O.; Gregson, R.K.; Clough, J.B. Small size at birth and greater postnatal weight gain: Relationships to diminished infant lung function. Am. J. Respir. Critic. Care Med. 2004, 170, 534-540. [CrossRef] [PubMed]

61. Tauber, E.; Gartner, C.; Halmerbauer, G.; Rath, R.; Schelberger, B.; Schierl, M.; Frischer, T. Predictors of lung function in infants at high risk of atopy: Effect of allergen avoidance. Respir. Med. 2002, 96, 230-235. [CrossRef] [PubMed]

62. Hancox, R.J.; Poulton, R.; Greene, J.M.; McLachlan, C.R.; Pearce, M.S.; Sears, M.R. Associations between birth weight, early childhood weight gain and adult lung function. Thorax 2009, 64, 228-232. [CrossRef] [PubMed]

63. Pike, K.C.; Crozier, S.R.; Lucas, J.S.; Inskip, H.M.; Robinson, S.; Roberts, G.; Godfrey, K.M. Patterns of fetal and infant growth are related to atopy and wheezing disorders at age 3 years. Thorax 2010, 65, 1099-1106. [CrossRef] [PubMed]

64. Hersoug, L.G.; Linneberg, A. The link between the epidemics of obesity and allergic diseases: Does obesity induce decreased immune tolerance? Allergy 2007, 62, 1205-1213. [CrossRef] [PubMed]

65. Boulet, L.P. Obesity and atopy. Clin. Exp. Allergy J. Br. Soc. Allergy Clin. Immunol. 2015, 45, 75-86. [CrossRef]

66. Imai, C.M.; Gunnarsdottir, I.; Thorisdottir, B.; Halldorsson, T.I.; Thorsdottir, I. Associations between infant feeding practice prior to six months and body mass index at six years of age. Nutrients 2014, 6, 1608-1617. [CrossRef]

67. Thorisdottir, B.; Gunnarsdottir, I.; Thorisdottir, A.V.; Palsson, G.I.; Halldorsson, T.I.; Thorsdottir, I. Nutrient intake in infancy and body mass index at six years in two population-based cohorts recruited before and after revision of infant dietary recommendations. Ann. Nutr. Metab. 2013, 63, 145-151. [CrossRef]

68. Smith, H.A.; Becker, G.E. Early additional food and fluids for healthy breastfed full-term infants. Cochrane Database Syst. Rev. 2016, Cd006462. [CrossRef]

69. Gunnarsson, O.; Indriethason, O.S.; Franzson, L.; Halldorsdottir, E.; Sigurethsson, G. Vitamin-D homeostasis amongst adult Icelandic population. Laeknabladid 2004, 90, 29-36. [PubMed]

70. Steingrimsdottir, L.; Gunnarsson, O.; Indridason, O.S.; Franzson, L.; Sigurdsson, G. Relationship between serum parathyroid hormone levels, vitamin D sufficiency, and calcium intake. JAMA 2005, 294, 2336-2341. [CrossRef] [PubMed]

71. Hypponen, E.; Berry, D.J.; Wjst, M.; Power, C. Serum 25-hydroxyvitamin D and IgE-A significant but nonlinear relationship. Allergy 2009, 64, 613-620. [CrossRef] [PubMed]

72. Hollams, E.M.; Teo, S.M.; Kusel, M.; Holt, B.J.; Holt, K.E.; Inouye, M.; De Klerk, N.H.; Zhang, G.; Sly, P.D.; Hart, P.H.; et al. Vitamin D over the first decade and susceptibility to childhood allergy and asthma. J. Allergy Clin. Immunol. 2017, 139, 472-481. [CrossRef] [PubMed] 
73. Thorisdottir, B. Vitamin D in Northern Latitudes. Intake and Status in Icelandic Children. Ph.D. Thesis, Faculty of Food Science and Nutrition, University of Iceland, Reykjavík, Iceland, 2018.

74. Suaini, N.H.; Zhang, Y.; Vuillermin, P.J.; Allen, K.J.; Harrison, L.C. Immune modulation by Vitamin D and its relevance to food allergy. Nutrients 2015, 7, 6088-6108. [CrossRef] [PubMed]

75. Calder, P.C. The relationship between the fatty acid composition of immune cells and their function. Prostaglandins Leukotrienes Essent. Fatty Acids 2008, 79, 101-108. [CrossRef] [PubMed]

(C) 2019 by the authors. Licensee MDPI, Basel, Switzerland. This article is an open access article distributed under the terms and conditions of the Creative Commons Attribution (CC BY) license (http://creativecommons.org/licenses/by/4.0/). 